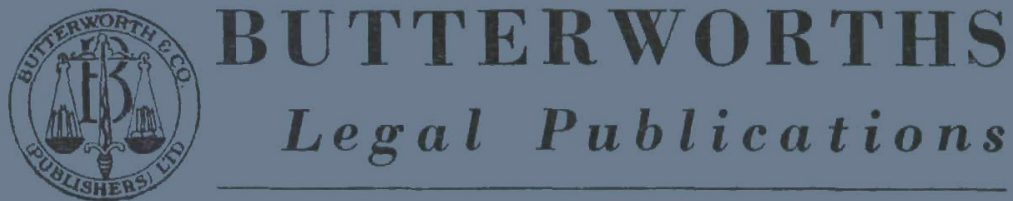

\title{
STEPHEN'S COMMENTARIES on THE LAWS OF ENGLAND
}

21st lidilion, 1950. Editor-in-Chief: I. Crispin Warmington, Solicitor of the Supreme Court (Honours).

"Indenl, il a treatise sets out to provide' a complete elementary statement of the law of England'. . . it is difficult to see how this ambitious asm conld have been better achieved. It is quite astonishing how much is covered ... -Law Notes.

In four volumes and supplement, price $\mathfrak{E} 6$ 15s. per set, post froe

\section{JENKS' ENGLISH CIVIL LAW}

1th. Eidition, 1917. General Editor, P. H. Winfield, LL.D.(1 antab.), Hon. I.I.I).(Harvard and I.eeds), K.(., F.B.A., limeritus Professor of English Law in the University of Cambridge, Fellow of St. John's College, Cimbridge; Honorary Bencher of the Inner Temple.

.. The student who desires a summary of English Private Law with historical notes, judicial decisions and copious cross-references, will find these volumes a capital investment which will yield rich dividends for many Years. "-Law Notes.

$$
\text { In turo volumes, price } £ 5 \text { l6s, per set, post free }
$$

\section{JAMES'S INTRODUCTION to ENGLISH LAW}

1950. By PuLip S. Janes, I.A., of the Inner Temple, Barristerat-Lau, formerly Fellom of Exeter Collegc, Oxford.

This new book has been written to introduce the student to the basic principles of English law. University students of law will obtain from it a background to their further studies.

". The real value of the book is that it is lounded on profound scholarship und sond learning and that its siyle is clear and concise." - The Law Times.

Price 12s. Gil., post free

\section{KEE \& COWPER-COLES' DIVORCE CASE BOOK}

1950. By WilLiam KeE, of the Inner Temple, and the South-Eastern Cireuit, Barrister-at-Law and SumRarn Cowper-('oles of the Inner Temple, Barrister-at-Law. Consulting liditor, Geofrney Tynuale, one of His Majesty's Counsel, a Bencher of the Inner Temple.

" Divoree practitioners and students aike will welenme the appearance of this new book, designed primarily to present a readable foundation to the statute and case law relating to divorce matters." - The Law Society's Gazctte.

Price $\notin 111$. $6 d$, post freb

BUTTERWORTH \& CO. (Publishers) LTD. BELL YALD :: TEMPLE BAR :: LONDON W.C.2 


\section{The Finest Service Ever Offered to the Profession}

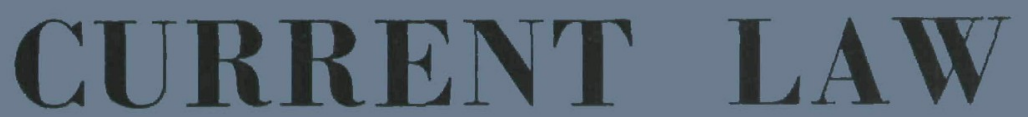

General Editor: JOHN BURKE, Burrister-at-Luu

\section{MONTHLY PARTS}

Currexr Law is published on the sth of each month and presents MLL. THE I.AW for the preceding month in a convenient and readulsle form. It covers all reported decisions of the English Courts; the relevant Scottish and Irish decisions; all dets of Parliament and Church of England Measures; all rules and orders; command papers, circulars and ofticial statements, and articles in the weekly, monthly, quarterly and annual periodicals.

Curnest Law is arranged under titles and sub-titles chosen with a view to making the work a universal supplement to all law books.

The valuable new Case Citator gives in a single alphabetical table not only the new cases but also (in distinctive type) all ather cases which have been commented on during the year. The whole law for the year is made continuously and instantly available by a cumulative index which is revised every month.

\section{YEAR BOOK}

At the end of the year the monthly parts of CURRENT LAW are superseded by a Year Book. This is not a mere reprint of the monthy parts, but a new consolidated statement of the law for the year arranged alphabetically under headings.

\section{STATUTES}

Curnase Law STamtes are issued with annotations as soon as possible after they receive the Royal Assent. Each part contains a Cumulative Annotations Supplement, Cumulative Statute Citator (showing statutory amendments, statutory instruments and cases on construrtion) and Cumulative Index.

\section{RATES OF SUBSGRIPTION}

Service "A" CURRENT LAW monthly parts.

"CuRrent Law" YEAR BOOK

"Current Law" STATUTES ... ... ... £4 14s. $6 \mathrm{~d}$.

Service "B" CURRENT LAW monthly parts.

"Current law" YEAR boOK $\quad \ldots \quad \ldots \ldots 33$ 3s. $0 \mathrm{~d}$.

Service "C" CURRENT LAW monthly parts

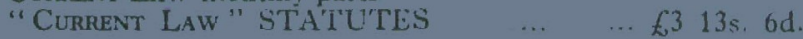

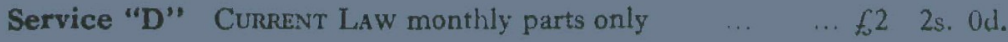

Service "E" "CURRENT LAW" YEAR BOOK alone $\quad \ldots £ 2$ 2s, Od.

Service "F" "Current LAw" STATUTES aione $\ldots \ldots \ldots £ 2 \quad 2 s .0 \mathrm{~d}$. 